
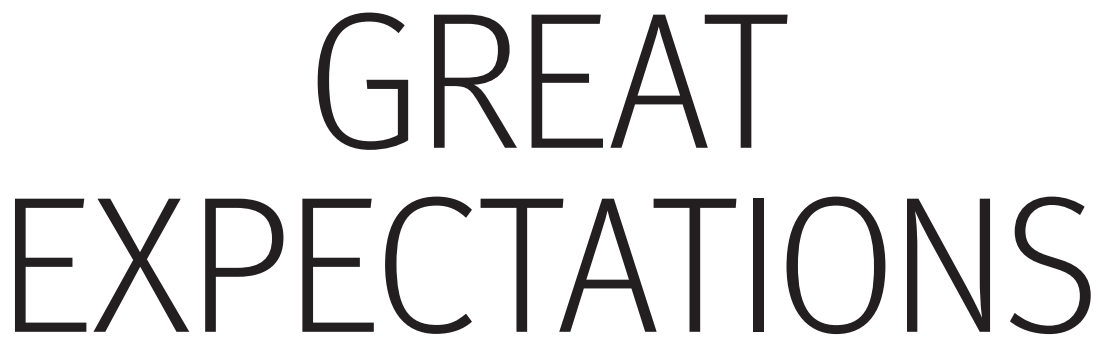

The Bill and Melinda Gates Foundation is the world's biggest grant giving charity and has done much to raise the profile of global health. But critics claim its special brand of philanthropy

is damaging health systems in developing countries and distorting aid priorities. Hannah Brown reports

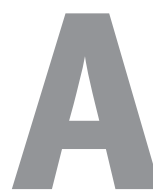
sk anyone with a passing interest in global health what the Gates Foundation means to them and you'll likely get just one answer: money. In a field long fatigued by the perpetual struggle for cash, the foundation's eagerness to finance projects neglected by many other donors raised high hopes among campaigners that its impact on health would be swift and great. And with the commitment last June by America's second richest man, Warren Buffet, to effectively double the foundation's \$30bn (£15bn; $€ 22 \mathrm{bn}$ ) endowment, ${ }^{1}$ hopes of substantial health achievements grew higher still.

But despite Bill Gates's prediction at a press conference to mark Buffet's pledge that there was now "No reason why we can't cure the top 20 diseases" ${ }^{2}$ observers are starting to question whether all this money is reaping

\section{WHERE THE GATES MONEY GOES}

\section{Malaria \$642m}

Vaccine preventable diseases $\$ 1.9 \mathrm{bn}$

HIV and AIDS \$1.1bn

Child health $\$ 164 \mathrm{~m}$

Tuberculosis $\$ 321 \mathrm{~m}$

Nutrition $\$ 191 \mathrm{~m}$

Acute diarrhoeal illness $\$ 89 m$

Acute lower respiratory infections $\$ 239 \mathrm{~m}$

Reproductive and maternal health $\$ 522 \mathrm{~m}$

Other infectious diseases $\$ 596 \mathrm{~m}$

Breakthrough science $\$ 448 \mathrm{~m}$

Advocacy $\$ 532 \mathrm{~m}$

Emergency relief $\$ 61 \mathrm{~m}$

Grants from 1995-2005 listed in Gates Foundation Global Health Program Fact Sheet (March 2006)

www.gatesfoundation.org/nr/downloads/

globalhealth/GH_fact_sheet.pdf sufficient rewards. For although the foundation has given a huge boost to research and development into technologies against some of the world's most devastating and neglected diseases, critics suggest that its reluctance to embrace research, demonstration, and capacity building in health delivery systems is worsening the gap between what technology can do and what is actually happening to health in poor communities. This situation, critics charge, is preventing the Gates's grants from achieving their full potential.

As one of the Gates Foundation's three main focuses, along with global development and its US programme, global health projects receive a substantial amount of the charity's annual spending. To date, almost half of all awards have been in this area, a total of $\$ 6 \mathrm{bn}$. When the Gates Foundation first started this generous spending in 2000, it was greeted with enthusiasm as a refreshing alternative to the staid, sluggish agencies that had until that time dominated global health. More nimble than the bureaucratic intergovernmental organisations of the UN system, including the World Health Organization, the Gates Foundation won respect for prioritising research gaps, promoting new financing mechanisms, and embracing partnerships with key global health actors.

However, the foundation's business-like approach has also gained its fair share of detractors. A commitment to results oriented spending ensures that money is linked to measurable and demonstrable outcomes. But although this strategy makes accounting easier to handle, it has perpetuated vertical,

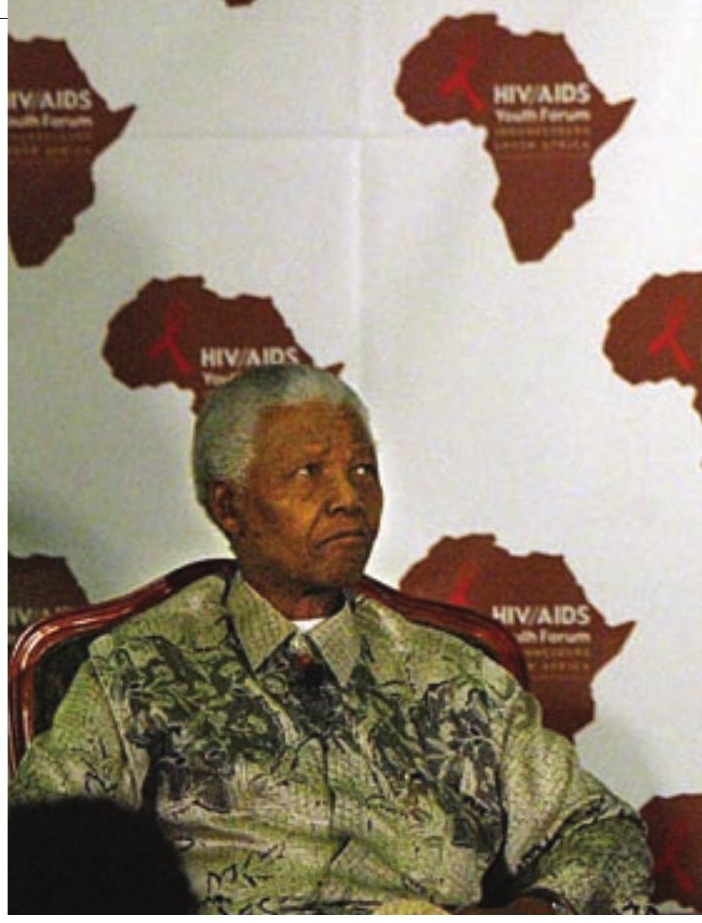

Are the Gates's grants achieving their full potential?

disease specific funding strategies that damage health systems in developing countries, according to David Sanders, director of the School of Public Health at the University of the Western Cape, South Africa.

These vertical programmes, which are a longstanding feature of many global health initiatives, lead to fragmentation of health systems because they require separate planning, staffing, and management from other health services. ${ }^{3}$ Although the programmes can efficiently meet short term targets, Professor Sanders says such successes come at the expense of sustainable improvements in health. "Unless there has been a very concerted effort at preserving local capacity and ensuring retention of staff then it is not a sustainable approach," he says. What is more, he adds, vertical programmes tend to distort government priorities in developing countries, even if local ministers are committed to broad health system improvements. "Even if governments develop coherent policies and integrated plans it is quite difficult to hold that line when your big funders - with more money than those countries' overall health budgets — want to focus on single diseases, often using a single technology rather than a more comprehensive approach," explains Professor Sanders.

\section{Technology versus delivery}

Whereas the foundation contests claims that it is neglecting the strengthening of health systems, co-chairs Bill and Melinda Gates 


\section{PRAISE AND CRITICISM FOR THE GATES FOUNDATION}

\section{Pros}

Raised profile of global health

Forced UN and other agencies to rethink role Created a more stable environment for research Brought in much needed funds
Cons

Focus on technology rather than delivery

Perpetuated vertical programmes; not strengthening existing health systems Funding mainly goes to northern organisations Too slow to make decisions Not sufficiently accountable from the very distortions and injustices in the global political economy that keeps billions of people impoverished and unable to access health care. "The mere fact that we have one individual able to concentrate and accumulate so much wealth points to more fundamental questions about the way that the global political economy is organised, and we need a bigger discussion about how to shift the proceeds of economic growth to more people," he says. He adds that while even grand-scale grant giving may seem to be a beneficial action, philanthropy can actually make underlying social and economic problems - the true determinants of health-more difficult to resolve because it can hinder health system development.

Finally, as with all private philanthropic organisations, the Gates Foundation attracts criticism for the simple reason that its money is private and therefore not really open to public accountability. According to Dr McCoy, the large degree to which the foundation has become a funder of independent academic institutions, non-governmental organisations, global health agencies, and even journalists raises concerns about self censorship and a reluctance to subject itself to proper scrutiny. The foundation counters that it is continuously striving for openness through providing detailed information about grants on its website and seeking external opinions on some funding requests.

For some, however, having to rely on the foundation's commitment to accountability is not sufficient, given the influence it enjoys. Anne-Emanuelle Birn, Canada chair in international health at the University of Toronto, thinks that because the foundation only partfunds most initiatives, and selectively picks good performers, that its decisions influence other donors' choices about where to put their money. This means, according to Dr Birn, that although the Gates Foundation's grants may not be making a huge impact on the ground, it is substantially affecting global health priorities.

"When the Gates Foundation invests there are a whole range of bilateral agencies and governments that are interested in joining on," says Dr Birn. "Organisations want to be associated with what are perceived to be successful initiatives." And this influence on how taxpayers' money is spent should, she argues, confer greater responsibility. Dr Birn, Dr McCoy, and Professor Sanders all share the belief that the Gates Foundation-and Bill Gates himself — should use its profile and clout in financial circles to lobby for changes to improve the economic condition of developing countries as well as funding health programmes.

\section{Positive effect}

One thing observers do not contest is that in the seven years since the foundation was set up, it has been a key advocate for global health as an issue of international concern. "The field is not treated any more like a charity side show in part because Gates entered with money and has given the field visibility," says Professor Chen. And, importantly, the foundation's existence has prompted the traditional global health actors to take a much-needed look at what niche they can occupy now. For example, says Professor Mills, "because Gates is coming with an awful lot of money it has stimulated the [Unicef, UN Development Programme, World Bank, and WHO sponsored] Special Programme for Research and Training in Tropical Diseases to rethink its core business to focus on southern partnerships and developing capacity because it can't compete in terms of the volume of money for scientific investments."

The foundation has also created a more stable environment for research. Professor
Mills says the scale of the funding available through the foundation has enabled a different approach to research from that allowed by the necessarily restricted traditional sources of global health funding. "The research agenda surrounding potential new tools, such as intermittent presumptive treatment of malaria in infants, can now be addressed in a set of coordinated studies, rather than piecemeal as funding permits," she explains. However, to make the organisation more successful in terms of global health outcomes, she agrees that it must extend its funding to aid countries with policy choices and decision making. "My hope is that Gates will come to realise they do have to engage with health systems research. If they don't we will have many new technologies but they won't get used," says Professor Mills.

While conceding that "the initial funding hasn't yet translated into anything dramatic in the field," Professor Chen believes that Bill and Melinda Gates at least seem to have the right motivation for the task of co-chairing the world's biggest grant-giving charity. "I think they are honestly trying to do a good job," he says. "Much of the innovation and creativity of philanthropy is about taking some risks to achieve breakthrough results."

Hannah Brown is a freelance journalist

hannah@two-cultures.com

Competing interests: None declared.

1 Noguchi Y. Gates Foundation to get bulk of Buffett's fortune. Washington Post 2006 Jun 26 www.washingtonpost.com/wp-dyn/content/ article/2006/06/25/AR2006062500801.htm

2 BBC News Online. Buffett donates \$37bn to charity. Jun 26, 2006. http://news.bbc.co.uk/1/hi/5115920.stm

3 Travis P, Bennett S, Haines A, Pang T, Bhutta Z, Hyder $A A$, et al. Overcoming health-systems constraints to achieve the millennium development goals. Lancet 2004;364:900-6.

4 Flexner A. Medical education in the United States and Canada. New York: Carnegie Foundation for the Advancement of Teaching, 1910. www. carnegiefoundation.org/files/elibrary/flexner report. pdif

5 Welch WH, Rose W. Welch-Rose report on schools of public health. New York: Rockefeller Foundation, 1915.

6 Piller C, Sanders E, Dixon R. Dark cloud over good works of Gates Foundation. LA Times 2007 Jan 7. www.latimes.com/news/nationworld/nation/laha-gatesx07jan07,0,6827615.story?coll=la-home headlines

7 Piller C. Money clashes with mission: The Gates Foundation invests heavily in sub-prime lenders and other businesses that undercut its good works. LA Times 2007 Jan 8. www.latimes.com/news/nationworld/ hation/la-na-gates8jan08,0,7911824.story?coll=lahome-headlines

8 Scott C. Our investment philosophy. Seattle: Gates Foundation, Jan 2007. www.gatesfoundation.org/ AboutUs/Announcements/Announce-070109.htm 